\title{
МЕТОДИКА ОБРОБКИ КУКСИ ПІСЛЯ ВИКОНАННЯ ВИСОКОЇ ТРАНСМЕТАТАРЗАЛЬНОї АМПУТАЦІї СТОПИ ЗА ШОПАРОМ
}

\author{
๑Ю. М. Футуйма, А. Д. Беденюк, А. В. Павлишин, П. Я. Боднар
}

Тернопільський начіональний медичний університет імені І. Я. Горбачевського МОЗ України

PЕзЮМЕ. Сьогодні у всьому світі цукровий діабет (ЦД) визнаний одним із найважливіших неінфекційних захворювань, поширення якого набуло характеру пандемії. Переважно цьому сприяють збільшення численності та віку населення планети, урбанізація території, ожиріння і малорухомий спосіб життя. Загалом на пацієнтів, хворих на цукровий діабет, ускладнений синдромом діабетичної стопи (СДС), припадає 40-70 \% ампутацій нижніх кінцівок нетравматичного ґенезу, які в цій групі хворих виконуються в 10-15 разів частіше, ніж у загальній популяції.

Мета - на основі запропонованої оптимізації методики «малих» ампутацій удосконалити відомий спосіб високої ампутації стопи за Шопаром шляхом зменшення кількості гострих кутів зони відпилу ураженої частини кістки.

Матеріал і методи. 3 використанням удосконаленої нами методики прооперовано 52 пацієнти віком від 42 до 80 років, які перебували на лікуванні в хірургічному та судинному відділеннях Тернопільської університетської лікарні з гнійно-некротичними ураженнями дистального відділу стопи на ґрунті цукрового діабету. Результати порівнювали з результатами контрольної групи пацієнтів, яким проводили високу трансметатарзальну ампутацію класичним методом пилою Джиглі.

Результати. Для ампутації кісткової тканини застосували відрізний металевий диск діаметром 22 мм, який за допомогою електроприводу обертається зі швидкістю до 20000 обертів за хвилину.

Місця відпиляних кісток, там де стикаються під кутом грані діафіза та відпилу кістки, обробляли шляхом поетапного шліфування корундовою кулеподібною 5-міліметровою шліфувальною насадкою впродовж 1-3 хвилини зі швидкістю обертання 10000 за хвилину та фінішною корундовою конусоподібною 5-міліметровою насадкою впродовж 2-4 хвилин зі швидкістю 15 000-20 000 обертів за хвилину, допоки гострі кути граней діафіза та відпилу кістки не набули на максимально округлої форми. Місця відпилу і шліфовки кістки закрили м'якими тканинами, формуючи таким чином куксу.

Висновки. Запропонований спосіб обробки місця відпилу кісток після виконання високої трансмететарзальної ампутації стопи за Шопаром забезпечив відсутність гострих кутів на місцях відпилу, що дозволило уникнути додаткового травмування навколишніх м'яких тканин, значно зменшило больові відчуття, скоротило строки загоєння ранових поверхонь та пришвидшило медичну і соціальну реабілітацію хворого.

КЛючовІ СлОВА: цукровий діабет; синдром діабетичної стопи; гнійно-некротичні ураження стоп.

Вступ. У структурі пізніх ускладнень ЦД синдром діабетичної стопи (СДС) займає провідні позиції, призводячи до зростання інвалідизації й смертності хворих цієї групи. Хронічні ранові дефекти нижніх кінцівок виникають у 15-25 \% хворих на ЦД та $\epsilon$ безпосередньою причиною високих ампутацій нижніх кінцівок у 12 \% хворих. Щогодини у світі виконують 55 ампутацій у хворих на ЦД, а в Україні частота трофічних уражень у хворих на СДС сягає $18 \%$, кількість високих ампутацій $-8,3-9 \%[1,3,5]$.

На сьогодні хірургічне лікування гнійно-некротичних процесів спрямоване на виконання у хворих на СДС органозберігаючих втручань на нижніх кінцівках - хірургічних обробок та «малих» ампутацій. Значна частина таких втручань призводить до порушень біомеханічного навантаження на стопу та виникнення великих ран, в яких на тлі ЦД спотворюється перебіг ранового процесу. Це сповільнює процеси загоєння ран та сприяє хронізації процесу, погіршуючи результати лікування. Тому триває пошук нових методик «малих» ампутацій на стопі $[4,6,8]$.
На сьогодні відомий спосіб «малих» ампутацій та наступної хірургічної обробки полягає в тому, що некротично уражену частину стопи видаляють за допомогою спеціального ампутаційного інструментарію (ампутаційного ножа, кусачок Люєра, кусачок Лістона, пили Джиглі) шляхом високої трансмететарзальної ампутації частини фаланг пальців за Шопаром, а місця відпилу кістки (ту частину, що залишилась) закривають м'якими тканинами, формуючи таким чином куксу $[2,7]$.

Недоліком цього способу $\epsilon$ те, що висока трансмететарзальна ампутація частини фаланг пальців за Шопаром здійснюється шляхом відпилу (резекції) частини некротизованої кістки та тканин у межах здорових тканин з наступним формуванням кукси, однак відома методика високого відпилу (резекції) кісток фаланг пальців залишає гострі ділянки кістки, тобто грані діафіза, та безпосередньо місця відпилу сходяться під кутом. Таке закінчення кісток після резекції має ряд суттєвих недоліків, оскільки формуються зони підвищеного тиску на тканини кінцівки, якими за- 
Огляди літератури, оригінальні дослідження, погляд на проблему, випадок з практики, короткі повідомлення кривають операційну рану, що, в свою чергу, подовжує строки регенерації ранових поверхонь і сприяє розвитку застійних явищ та ішемії тканин. Крім того, наявність зон підвищеного тиску на тканини зумовлює посилення в цих місцях больових відчуттів. Вищеозначені умови спричиняють поглиблення порушень біомеханіки стопи (змінюється розподіл маси тіла пацієнта як на здорову, так і на хвору кінцівку) і, як наслідок, збільшуються строки загоєння рани, медичної та соціальної реабілітації, погіршується психоемоційний стан хворого, знижується якість життя.

Мета - на основі запропонованої оптимізації методики «малих» ампутацій вдосконалити відомий спосіб високої ампутації стопи за Шопаром за рахунок зменшення кількості гострих кутів зони відпилу ураженої частини кістки.

Матеріал і методи дослідження. Запропоновану нами методику застосовано у 52 пацієнтів віком від 42 до 80 років, які перебували на лікуванні в хірургічному ту судинному відділеннях Тернопільської університетської лікарні з гнійнонекротичними ураженнями дистального відділу стопи на ґрунті цукрового діабету. Результати порівнювали з результатами контрольної групи пацієнтів, яким проводили високу трансметатарзальну ампутацію класичним методом пилою Джиглі. На даний час вказана методика подана для отримання патенту на винахід.

Результати й обговорення. Лікування, згідно з запропонованою методикою, виконували так: некротично уражену ділянку дистальної частини стопи видаляли шляхом високої трансметатарзальної ампутації за Шопаром. Безпосередньо для ампутації кісткової тканини застосовували відрізний металевий диск діаметром 22 мм, який за допомогою електроприводу обертається зі швидкістю до 20000 обертів за хвилину (рис. 1).

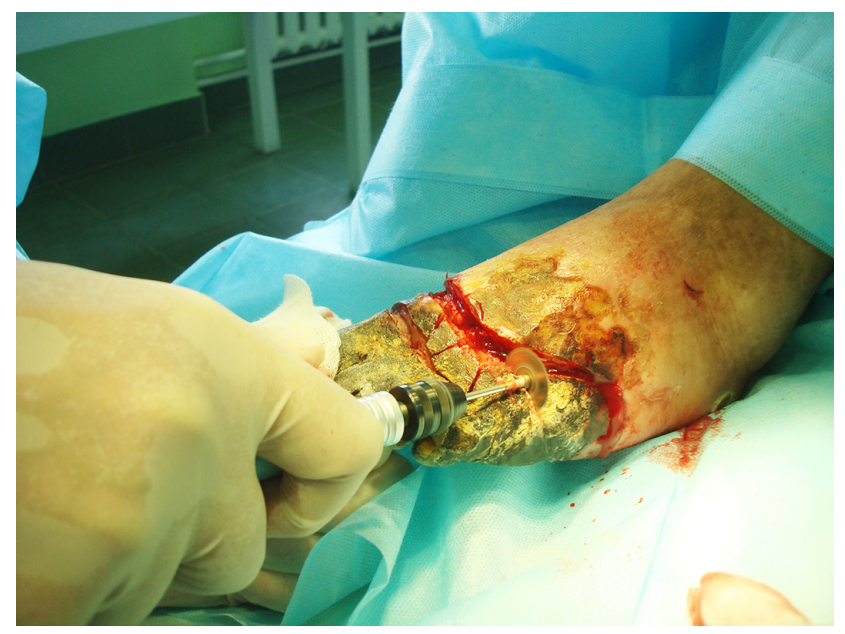

Рис. 1. Електромеханічне відсічення кісток ураженої частини стопи.
Місця відпиляних кісток, де стикаються під кутом грані діафіза та відпилу кістки, обробляли шляхом поетапного шліфування корундовою кулеподібною 5-міліметровою шліфувальною насадкою впродовж 1-3 хвилин зі швидкістю 10000 обертів за хвилину та фінішною корундовою конусоподібною 5-міліметровою насадкою впродовж 2-4 хвилин зі швидкістю 15 000-20 000 обертів за хвилину. Шліфування кожної кістки здійснювали поки гострі кути граней діафіза та відпилу кістки не були повністю зашліфовані і не набули максимально округлої форми. Місця відпилу і шліфовки кістки закривали м'якими тканинами, формуючи таким чином куксу. Закриття ранової поверхні здійснювали або класичним способом (за умови "живого» нижнього клаптя, в якому збережене кровопостачання) або ж проводили ранню автодермопластику на свіжу рану, не чекаючи росту грануляцій (рис. 2, 3).

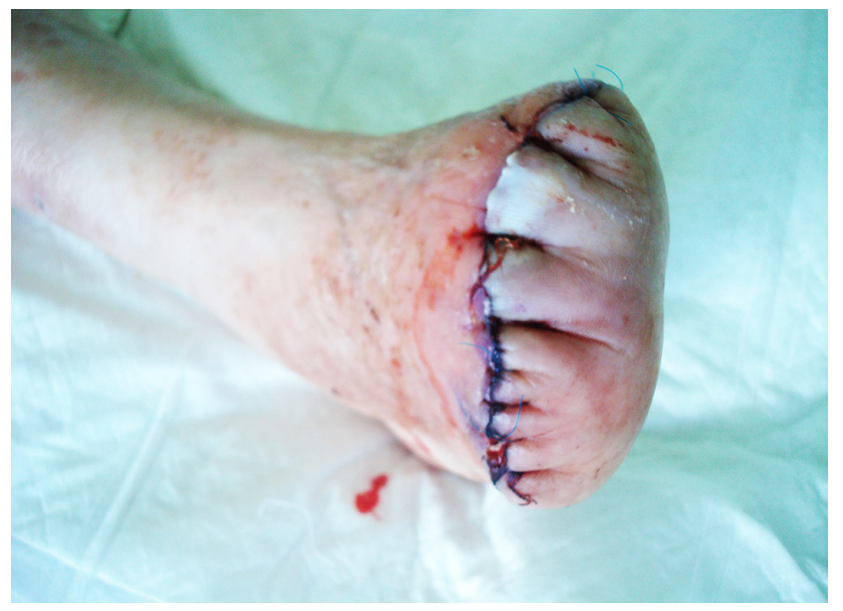

Рис. 2. Кукса, сформована нижнім клаптем.

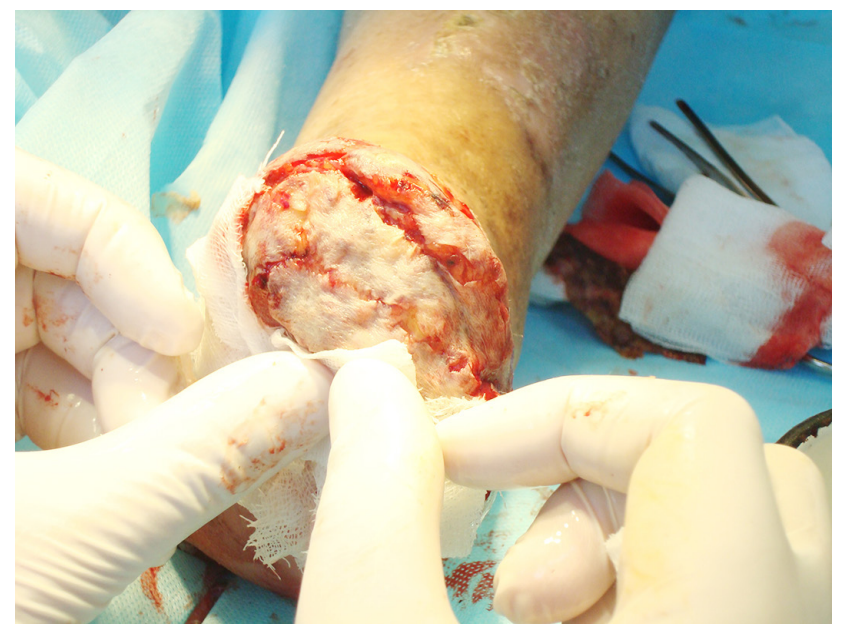

Рис. 3. Кукса закрита методом аутодермопластики.

На відміну від пацієнтів, у яких була виконана класична ампутація без обробки країв кісток запропонованим нами методом, у пацієнтів, яким за- 
Огляди літератури, оригінальні дослідження, поглядн на стосовували цей метод, в жодному випадку у віддаленому післяопераційному періоді не було виявлено розвитку ранових дефектів по підошвовій поверхні, не було болю при ходьбі та швидше загоювалися рани кукси.

Висновки. Запропонований спосіб обробки місця відпилу кісток після виконання високої трансметатарзальної ампутації стопи за Шопаром має ряд вагомих переваг, а саме - відсутність гострих кутів на місцях відпилу дозволяє уникнути додаткової травматизації навколишніх

\section{ЛІТЕРАТУРА}

1. Дедов И. И. Сахарный диабет - опаснейший вызов мировому сообществу // Вестник РАМН. - 2012. № 1. - С. 7-13.

2. Ляпіс М. О. Синдром стопи діабетика / М. О. Ляпіс, П. О. Герасимчук. - Тернопіль : Укрмедкнига, 2001. $276 \mathrm{c}$.

3. Митиш В. А. Оценка средней стоимости комплексного хирургического лечения нейроишемической формы синдрома диабетической стопы в рамках оказания высокотехнологичной медицинской помощи / В. А. Митиш, Ю. С. Пасхалова, Ф. Т. Махкамова // Материалы I Международного конгресса «Раны и раневые инфекции». - М., 2012. - С. 241-242.

4. Результаты бедренно-подколенных артериальных реконструкций в зависимости от гемодинамических условий / Д. Н. Майстренко, Ф. К. Жеребцов,

\section{REFERENCES}

1. Dedov, I.I. (2012). Saharnyy diabet - opasneyshyy vyzov mirovomu soobshchestvu [Diabetes mellitus is the most dangerous challenge to the world community]. Westnyk RAMN - Bulletin of the Russian Academy of Medical Sciences, 1, 7-13 [in Russian].

2. Liapis, M.O., \& Herasymchuk, P.O. (2001). Syndrom stopy diabetyka [Syndrome of the diabetic foot]. Ternopil: Ukrmedknyha [in Ukrainian].

3. Mitish, V.A., Paskhalova, Yu.S., \& Makhkamova, F.T. (2012). Otsenka sredney stoimosti kompleksnogo khirurgicheskogo lecheniya neyroishemicheskoy formy sindroma diabeticheskoy stopy v ramkakh okazaniya vysokotekhnologichnoy meditsinskoy pomoshchi [Estimation of the average cost of complex surgical treatment of the neuroischemic form of diabetic foot syndrome in the context of rendering high-tech medical care]. I Mezhdunarodnyy kongress "Rany i ranevyye infektsii" - Proceedings from I International Congress "Wounds and Wound Infections. "Moscow (pp. 241-242) [in Russian]. роблему, випадок з практики, короткі повідомлення м'яких тканин, значно зменшити больові відчуття, зменшити час загоєння ранових поверхонь (що особливо важливо для успішного формування кукси), пришвидшити медичну і соціальну реабілітацію хворого та покращити якість його життя.

Перспективи подальших досліджень. Застосування запропонованої нами методики та розробка нових методів обробки кісток при виконанні ампутацій на будь-якому рівні ураженої частини ступні.

Д. А. Гранов, К. А. Карлов // Вестник хирургии им. И. И. Грекова. - 2009. - Т. 168, № 4. - С. 41-44.

5. Удовиченко О. В. Диабетическая стопа / О. В. Удовиченко, Н. М. Грекова. - М. : Практическая медицина, 2010. -272 c.

6. Donath M. Y. Type 2 diabetes as an inflammatory disease / M. Y. Donath, S. E. Shoelson // Nat. Rev. Immunol. - 2011. - Vol. 11, No. 2. - P. 98-107.

7. Shaw J. E. Global estimates of the prevalence of diabetes for 2010 and 2030 / J. E. Shaw, R. A. Sicree, P. Z. Zimmet // Diabetes Res. Clin. Pract. - 2010. - Vol. 87, No. 1. P. 4-14.

8. Schramm J. C. Microvascular changes in the diabetic foot / J. C. Schramm, T. Dinh, A. Veves // The International Journal of Lower Extremity Wounds. - 2006. - Vol. 5. P. 149-159.

4. Maystrenko, D.N., Zherebtsov, F.K., Granov, D.A., \& Karlov, K.A. (2009). Rezultaty bedrenno-podkolennykh arterialnykh rekonstruktsiy $v$ zavisimosti ot gemodinamicheskikh usloviy [Results of femoral-popliteal arterial reconstructions depending on hemodynamic conditions]. Vestnik khirurgii im. I.I. Grekova - Bulletin of Surgery by I.I. Grekov, 168, 4, 41-44 [in Russian].

5. Udovichenko, O.V., \& Grekova, N.M. (2010). Diabeticheskaya stopa [Diabetic foot]. Moscow: Prakticheskaya meditsina [in Russian].

6. Donath, M.Y., \& Shoelson, S.E. (2011). Type 2 diabetes as an inflammatory disease. Nat. Rev. Immunol., 11, 2, 98-107.

7. Shaw, J.E., Sicree, R.A., \& Zimmet, P.Z. (2010). Global estimates of the prevalence of diabetes for 2010 and 2030. Diabetes Res. Clin. Pract., 87, 1, 4-14.

8. Schramm, J.C., Dinh, T., \& Veves, A. (2006). Microvascular changes in the diabetic foot. The International Journal of Lower Extremity Wounds, 5, 149-159.

\title{
МЕТОДИКА ОБРАБОТКИ КУЛЬТИ ПОСЛЕ ВЫПОЛНЕНИЯ ВЫСОКОЙ ТРАНСМЕТАТАРЗАЛЬНОЙ АМПУТАЦИИ СТОПЫ ПО ШОПАРУ
}

\author{
๑ю. М. Футуйма, А. Д. Беденюк, А. В. Павлишин, П. Я. Боднар
}

Тернопольский национальный медицинский университет имени И. Я. Горбачевского МОЗ Украины

PЕЗЮМЕ. Сегодня во всем мире сахарный диабет (СД) признан одним из важнейших неинфекционных заболеваний, распространенность которого приобрела характер пандемии. Преимущественно этому способствует 
Огляди літератури, оригінальні дослідження, погляд на проблему, випадок з практики, короткі повідомлення увеличение численности и возраста населения планеты, урбанизация территории, ожирение и малоподвижный образ жизни. В целом на пациентов, больных сахарным диабетом, осложненным синдромом диабетической стопы (СДС), приходится 40-70\% ампутаций нижних конечностей нетравматического генеза, которые в этой группе больных выполняются в 10-15 раз чаще, чем в общей популяции.

Цель - на основе предложенной оптимизации методики «малых» ампутаций усовершенствовать известный способ высокой ампутации стопы по Шопару за счет уменьшения количества острых углов зоны отпила пораженной части кости.

Материал и методы. С использованием методики, усовершенствованной нами, прооперировано 52 пациента в возрасте от 42 до 80 лет, которые находились на лечении в хирургическом и сосудистом отделениях Тернопольской университетской больницы с гнойно-некротическими поражениями дистального отдела ступни на почве сахарного диабета. Результаты сравнивали с результатами контрольной группы пациентов, которым проводилась высокая трансметатарзальная ампутация классическим методом пилой Джигли.

Результаты. Для ампутации костной ткани применяли отрезной металлический диск диаметром 22 мм, который с помощью электропривода вращается со скоростью до 20000 оборотов в минуту. Места отпиленных костей, там где сходятся под углом грани диафиза и отпила кости, обрабатывали путем поэтапнй шлифовки корундовой шаровидной 5-миллиметровой шлифовальной насадкой в течение 1-3 минут со скоростью вращения 10000 в минуту и финишной корундовой конусообразной 5-миллиметровой насадкой в течение 2-4 минут со скоростью 15 000-20 000 оборотов в минуту, пока острые углы граней диафиза и отпила кости не приобрели максимально округлой формы. Места отпила и шлифовки кости закрывали мягкими тканями, формируя таким образом культю.

Выводы. Предложенный способ обработки места отпила костей после выполнения высокой трансмететарзальной ампутации стопы по Шопару обеспечил отсутствие острых углов на местах отпила, что позволяет избежать дополнительной травматизации окружающих мягких тканей, значительно уменьшить болевые ощущения у пациентов, сократить сроки заживления раневых поверхностей и ускорить медицинскую и социальную реабилитацию больного.

КЛЮчЕВЫЕ слОВА: сахарный диабет; синдром диабетической стопы; гнойно-некротические поражения стоп.

\title{
METHOD OF CULTURAL PROCESSING AFTER COMPLETION OF HIGH TRANSMETATARAL FEET AMPUTATION BY SHOPAR
}

\author{
OYu. M. Futujma, A. D. Bedenyuk, A. W. Pawlyshyn, P. Ya. Bodnar \\ I. Horbachevsky Ternopil National Medical University
}

SUMMARY. Today, worldwide diabetes mellitus (DM) has been acknowledged by leading medical specialists as one of the most important non-communicable diseases, the prevalence of which has become pandemic. This is largely due to an increase in the population and age of the planet population, urbanization of the territory, obesity and sedentary lifestyles. In general, patients with diabetes mellitus, complicated by diabetic foot syndrome (DFS) undergo $40-70 \%$ of amputations of the lower limbs of nontraumatic genesis, which in this group of patients are performed 10-15 times more often than in the general population.

The aim of the study - on the basis of the proposed optimization of the technique of "small" amputations to improve the known method of high amputation of foot by Shopar by reducing the number of acute angles of the dent of the affected part of the bone.

Material and Methods. The technique, improved by us, was used for 52 patients aged 42 to 80 years who were treated at the surgical vascular departments of the Ternopil University Hospital with purulent necrotic lesions of the distal foot on the basis of diabetes mellitus. The results were compared with the control group of patients undergoing high transmetatarsal amputation by the classic Jigli saw blade.

Results. For amputation of bone tissue, a cut metal disk with a diameter of $22 \mathrm{~mm}$ was used which, with the help of the electric drive, rotates at a speed up to 20000 revolutions per minute. Spotted bones where the faces of diaphysics and bacillus face at an angle are treated by gradual grinding with a corundum grinding nozzle of $5 \mathrm{~mm}$ in the form of a layer for 1-3 minutes at a speed of 10.000 per minute and a $5 \mathrm{~mm}$ corundum nozzle with a cone for $2-4$ minutes at a speed of 15.000-20000 revolutions per minute until the sharp edges of the diaphyses and backside faces did not turn into the most rounded shape. Separating sites and sanding bones were covered with soft fabrics, forming a token thus.

Conclusions. The proposed method of treating bone sputum after performing high transmetatarial amputation of the foot on the Shapora ensured the absence of sharp corners in the spit areas, which made it possible to uniquely traumatize the surrounding soft tissues, greatly reduced the patient's sensation, shortened the period of healing of the wound surfaces, and accelerated the medical and social rehabilitation of the patient.

KEY WORDS: diabetes mellitus; diabetic foot syndrome; purulent necrotic lesions of the feet.

Отримано 20.03.2019 